\title{
Patients' safety: is there a systemic release of gentamicin by gentamicin-coated tibia nails in clinical use?
}

This article was published in the following Dove Press journal:

Therapeutics and Clinical Risk Management

7 September 2016

Number of times this article has been viewed

\author{
Arash Moghaddam' \\ Viola Graeser' \\ Fabian Westhauser' \\ Ulrike Dapunt ${ }^{\prime}$ \\ Till Kamradt \\ Stefan MWoerner ${ }^{2}$ \\ Gerhard Schmidmaier' \\ 'HTRG - Heidelberg Traume Research \\ Group Center for Orthopedics, \\ Trauma and Spinal Cord Injury, \\ University Hospital Heidelberg, \\ Heidelberg, Germany; ${ }^{2}$ Department \\ of Internal Medicine and Clinical \\ Chemistry, University Hospital \\ Heidelberg, Heidelberg, Germany
}

Introduction: Osteitis is one of the most serious complications in orthopedic surgery. Expert Tibia Nail (ETN) PROtect ${ }^{\mathrm{TM}}$ coated with a biodegradable layer of gentamicin-laden polymer was developed for prophylaxis of osteomyelitis. In systemic administration, gentamicin has only a small therapeutic index and serious side effects; it is potentially nephrotoxic as well as ototoxic. It is not yet known if relevant gentamicin concentrations are released into the systemic circulation after implantation of gentamicin-coated nails. In order to evaluate the patients' risks profiles and increase patient safety, we measured gentamicin levels in pre- and postoperative serum samples of patients undergoing implantation of ETN PROtect.

Methods: Twenty-five patients who received ETN PROtect between March 2012 and August 2014 were included in this study. Collection of blood samples occurred before the operation, at weeks 1-4, 3 and 6 months, and up to 1 year after the implantation. Measurement of gentamicin levels in serum samples was performed at the central laboratory of Heidelberg University Hospital. Additionally, laboratory parameters, C-reactive protein, leukocyte number, urea and creatinine concentrations were analyzed in routine controls before and after operating and assessed for systemic side effects.

Results: Over the course of this prospective observational study, we were able to determine that gentamicin-coated nails do not release gentamicin into the systemic circulation above the lowest detectable level of $0.2 \mathrm{mg} / \mathrm{dL}$. There were slight increases in the mean inflammation and renal retention markers, but no gentamicin-associated side effects could be linked to implantation. Furthermore, no allergic reactions could be detected during our study.

Conclusion: Our findings suggest that there is no relevant release of gentamicin into the systemic circulation causing a systemic effect, and serious side effects due to gentamicin-coated tibia nails should not be feared. Postoperative monitoring of renal function does not seem necessary because of the implantation of ETN PROtect.

Keywords: osteomyelitis, osteitis, pseudoarthrosis, fracture, therapy, ETN PROtect, implant, infection, tibia

\section{Introduction}

Osteitis is a serious complication in today's bone reconstructive medicine. ${ }^{1-3}$ To date (July 2011), PROtect-coated tibial nails have been successfully implanted in over 100 patients. In general treatment of osteitis is rather difficult, with the danger for severe complications such as the threat of losing the extremity or even death in cases of sepsis. ${ }^{3-6}$ Especially, open fractures after high energy trauma are at risk of infections. ${ }^{7-10}$ Depending on the severity of the fracture, infection rates range from $6 \%$ to $33 \% .^{1,10,11}$ Noteworthy is that up to $80 \%$ of all deep infections developed in Gustilo grade III open fractures. ${ }^{12,13}$
Correspondence: Arash Moghaddam HTRG- Heidelberg Trauma Research Group Center of Orthopaedics, Trauma Surgery and Spinal Cord Injury, Schlierbacher Landstraße 200a, D-69/18, Heidelberg, Germany

Tel +49 622I 5635394

Email Arash.Moghaddam@med.uniheidelberg.de hereby accept the Terms. Non-commercial uses of the work are permitted without any furcher permission from Dove Medical Press Limited, provided the work is properly attributed. For permission for commercial use of this work, please see paragraphs 4.2 and 5 of our Terms (https://www.dovepress.com/terms.php). 
Systemic administration of antibiotics is a routine procedure for prophylaxis of infections in orthopedic surgery..$^{14}$ Also, systemic prophylaxis has been proven effective; different approaches for antibiotic delivery are becoming more important (antibiotic-impregnated collagen sponges, polymethylmethacrylate beads, and antibiotic-coated implants). ${ }^{1,15-18}$ Furthermore, local application of antibiotics allows for higher doses of antibiotics without risking serious systemic side effects. ${ }^{3}$ Antibioticcoated implants could be an opportunity to end the vicious cycle of infection, multiple revision surgeries, and impaired healing by impeding bacterial colonization and reducing the risk of developing a biofilm on the implants' surface., ${ }^{3,19-21}$

For the treatment of extra-articular tibial defects, intramedullary nailing is currently the gold standard. ${ }^{10,22} \mathrm{SYN}-$ THES (SYNTHES AG GmbH, DePuy Synthes Companies, Zuchwil, Switzerland) special antibiotic-coated nails were introduced in 2005 as a universal intramedullary implant for tibial fractures. Up to 2011, over 100 patients were treated with unreamerd tibia Nail (UTN) PROtect or Expert Tibia Nail (ETN) PROtect ${ }^{\mathrm{TM}}$. ETN PROtect (DePuy Synthes Companies, Zuchwil, Switzerland) consists of an alloy of titanium, aluminum, and niobium and is coated with an absorbable poly (D, L-lactide) (PDLLA) matrix in which gentamicin sulfate is incorporated. According to the manufacturer, the ETN PROtect is intended for use in open fractures (GustiloAnderson Grade I to III), revision surgeries after infection, after polytrauma and in immunosuppressed patients. ${ }^{3}$

Gentamicin is an antibiotic of the aminoglycoside group. ${ }^{23,24}$ Its spectrum of action covers most Gram-negative bacteria as well as Staphylococcus aureus. ${ }^{24}$ Therefore, its active spectrum includes the most common bacterial strains involved in infections after orthopedic surgeries or following open fractures, ${ }^{25-27}$ namely staphylococcus species, which was found in $50 \%-80 \%$ of infections in an orthopedic setting. ${ }^{19,27}$ However, gentamicin is potentially nephrotoxic and ototoxic, and renal function should be monitored during the time of systemic administration. ${ }^{28,29}$ Contraindications for the systemic administration of gentamicin are current pregnancy, inner ear damage, renal insufficiency, myasthenia gravis, and co-medication with other nephrotoxic or ototoxic drugs. Furthermore, a known allergy against gentamicin is a contraindication for use.

Although gentamicin would be suitable for treating osteitis ${ }^{18}$ it is not a standard drug for systemic antibiotic prophylaxis in orthopedic surgery because of serious dosedependent side effects and a small therapeutic index..$^{14,23}$ A systemic administration of gentamicin is limited to cases of serious infections, when other antibiotics do not work. To hinder complications, therapeutical drug monitoring of gentamicin levels in serum is established.

It has already been shown in experimental research that locally administrated gentamicin does not influence bone healing in a negative way. ${ }^{30}$ However, it is not known if gentamicin-coated implants cause a relevant systemic exposure to gentamicin. If so, possible contraindications and side effects have to be considered before surgery, and renal function should be monitored after implantation. Previously, we observed a successful application in patients at risk for infection. ${ }^{3}$

In this study, we investigated how safe ETN PROtect is in a clinical setting, especially its systemic impact, nephrotoxic side effects, and allergenicity. Therefore, gentamicin levels were determined in serum samples taken before and after implantation of ETN PROtect.

\section{Patients and methods}

\section{Patients}

This study was conducted in accordance with the Declaration of Helsinki. ${ }^{31}$ All individuals followed the study protocol. The study was approved by the ethics committee of the Ruprecht-Karls-University of Heidelberg (S-636/2011). Patients $(\mathrm{n}=24)$ underwent implantation of ETN PROtect/ gentamicin-coated tibia nails between March 2012 and August 2014 at our clinic, and were included in the study. Patients were over the age of 18 and gave formal written consent for surgical treatment. Due to fracture of the nail, one patient had to undergo two operations within an interval of 8 months, and both times a coated nail was used. From this patient at both operations tissue and blood samples were collected; therefore in total 25 cases $(n=25)$ from 24 different patients were taken into account.

\section{Serum samples}

Peripheral blood samples were drawn over a period of 1 year following a standardized time pattern, as seen in Figure 1.

Blood was taken by venipuncture (S-Monovette ${ }^{\circledR}$; SARSTEDT, Nümbrecht, Germany) followed by centrifugation for 10 minutes at $15^{\circ} \mathrm{C}$ at $3,000 \mathrm{rpm}$ in a Rotixa $50 \mathrm{RS}$ (Fa.

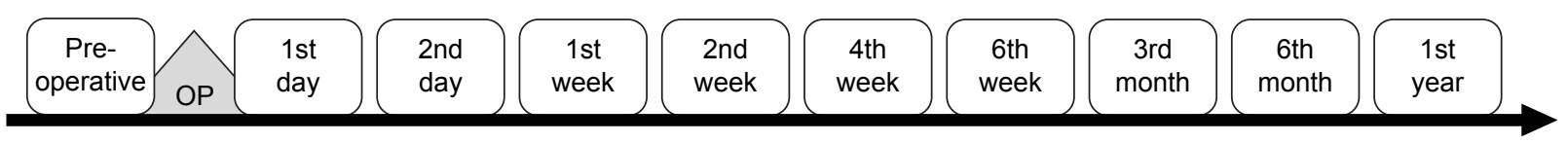

Figure I Time points of blood sampling.

Abbreviation: OP, operation. 
Hettich, Tuttlingen, Germany). Supernatant was pipetted into $1.5 \mathrm{~mL}$ Eppendorf ${ }^{\circledR}$ reaction vessels and a minimum of $0.6 \mathrm{~mL}$ was aliquoted to each vessel. Serum samples were stored at $-80^{\circ} \mathrm{C}$ and only transported once on dry ice for measurement..$^{32,33}$

Analysis of serum samples was performed in the central laboratory of the Heidelberg University Hospital. Gentamicin concentrations were determined in thoroughly thawed serum samples using the Siemens ADVIA Centaur Gentamicin assay with a Siemens Advia Centaur XPT (Siemens Healthcare Gmbh Eschborn, Germany). Gentamicin quantitation was achieved by a competitive immunoassay using direct chemiluminescent technology - acridinium ester-labeled gentamicin derivative in the reagent for a limited amount of monoclonal mouse anti-gentamicin antibody, which was coupled to paramagnetic particles in the solid phase (REF 05223979; Siemens Healthcare Diagnostics, Erlangen, Germany). Using this method, the lowest possible detectable level of gentamicin was $0.2 \mathrm{mg} / \mathrm{L}$. Literature indicates that doses below $2.0 \mathrm{mg} / \mathrm{L}$ seems to be harmless. ${ }^{34,35}$

\section{Markers of renal retention and inflammation}

Urea and creatinine were examined as markers of renal retention. For inflammation, C-reactive protein (CRP) and leukocyte count were used. These parameters were gathered from routine controls before and after the operation and were accessible through patient charts. An initial burst of gentamicin was expected as noted in previous literature; therefore, we analyzed relevant laboratory parameters up to 6 days after the operation. ${ }^{36,37}$

\section{Statistics}

Mean values of laboratory parameters for all patients at different time points were descriptively analyzed. Standard deviations (SDs) for the assessed parameters and range were described.

\section{Results}

\section{Patients' characteristics}

Patients demographic details are shown in Table 1. The dates of the blood collections for each patient are given in Table 2. Body mass index in the patients' cohort ranged from 18.75 to $52.16 \mathrm{~kg} / \mathrm{m}^{2}$. The mean body mass index was $30.81 \mathrm{~kg} / \mathrm{m}^{2}$ with an SD of $7.23 \mathrm{~kg} / \mathrm{m}^{2}$.

\section{Measurement of gentamicin levels}

We were not able to detect gentamicin levels higher than the lowest detectable level of $0.2 \mathrm{mg} / \mathrm{L}$ in any of the 139 serum samples.

\section{Evaluation of markers for renal retention and inflammation markers}

The preoperative mean values of the collected laboratory parameters were $31.80 \mathrm{mg} / \mathrm{dL}$ with an SD of $5.82 \mathrm{mg} / \mathrm{dL}$ for urea, $0.95 \pm 0.14 \mathrm{mg} / \mathrm{dL}$ for creatinine, $7.53 \pm 2.22 \mathrm{~nL}^{-1}$ for leukocyte count, and 8.29 $\pm 9.21 \mathrm{mg} / \mathrm{L}$ for CRP. Except for $\mathrm{CRP}$, which has an upper reference range limit of $5 \mathrm{mg} / \mathrm{L}$, all initial values were within the reference range.

On average, the concentration of urea in patients' serum decreased from $32.22 \pm 13.00 \mathrm{mg} / \mathrm{dL}$ on the first day after operation to $19.67 \pm 3.43 \mathrm{mg} / \mathrm{dL}$ on the second day. It leveled between $25.00 \pm 7.29 \mathrm{mg} / \mathrm{dL}$ and $18.00 \pm 7.48 \mathrm{mg} / \mathrm{dL}$ on the following days (Figure 2).

The average creatinine levels increased from the time before the operation $(0.95 \pm 0.15 \mathrm{mg} / \mathrm{dL})$ to the first day after the operation $(1.04 \pm 0.24 \mathrm{mg} / \mathrm{dL})$, but dropped below the initial value on the following days, except on the fifth postoperative day $(0.98 \pm 0.17 \mathrm{mg} / \mathrm{dL})$ (Figure 3$)$.

In one patient, renal retention markers showed a noticeable increase: creatinine level rose from $1.1 \mathrm{mg} / \mathrm{dL}$ preoperatively to $1.4 \mathrm{mg} / \mathrm{dL}$ (reference range $<1.3 \mathrm{mg} / \mathrm{dL}$ ) postoperatively, the urea level likewise from 37 to $55 \mathrm{mg} / \mathrm{dL}$ (reference range $<45 \mathrm{mg} / \mathrm{dL}$ ). This was the only sample in which urea and creatinine levels above the upper reference range limit were detected.

$\mathrm{CRP}$ as a marker of inflammation showed on average an increase from $8.29 \pm 9.21 \mathrm{mg} / \mathrm{L}$ (reference range $<5 \mathrm{mg} / \mathrm{L}$ ) preoperatively to $47.29 \pm 19.51 \mathrm{mg} / \mathrm{L}$ on the first day, $72.66 \pm 23.48 \mathrm{mg} / \mathrm{L}$ on the second, and $82.96 \pm 66.41 \mathrm{mg} / \mathrm{L}$ on the third day postoperatively. A significant decrease was already apparent on the fourth day at $41.01 \pm 24.75 \mathrm{mg} / \mathrm{L}$. Subsequently, average CRP values approached the initial value. Several patients showed a CRP above $100 \mathrm{mg} / \mathrm{L}$, mostly on the second or third day after the operation, but all

Table I Patient demographics

\begin{tabular}{|c|c|c|c|c|c|c|c|c|c|c|c|c|c|}
\hline \multirow[t]{2}{*}{ Patients } & \multirow[t]{2}{*}{$\mathbf{N}$} & \multicolumn{2}{|l|}{ Sex } & \multirow{2}{*}{$\begin{array}{l}\text { Age } \\
\text { Years } \\
\text { (mean } \pm \text { SD) }\end{array}$} & \multicolumn{4}{|c|}{ Fracture } & \multicolumn{2}{|c|}{ Localization } & \multicolumn{2}{|c|}{ Previous infection } & \multirow{2}{*}{$\begin{array}{l}\text { Previous } \\
\text { surgeries } \\
\text { Mean }\end{array}$} \\
\hline & & Female & Male & & Closed & $1^{\circ}$ & $2^{\circ}$ & $3^{\circ}$ & Left & Right & Positive & Negative & \\
\hline All & 25 & 7 & 18 & $50.92 \pm 12.00$ & 13 & I & 2 & 8 & 6 & 19 & 6 & 19 & 3.92 \\
\hline
\end{tabular}


Table 2 Dates (dd/mm/yy) of blood collection for gentamicin detection for each patient

\begin{tabular}{|c|c|c|c|c|c|c|c|c|c|c|c|c|}
\hline Number & Sex & $\begin{array}{l}\text { Age, } \\
\text { years }\end{array}$ & Preoperative & $\begin{array}{l}\text { After } \\
\text { I day }\end{array}$ & $\begin{array}{l}\text { After } \\
2 \text { days }\end{array}$ & $\begin{array}{l}\text { After } \\
\text { I week }\end{array}$ & $\begin{array}{l}\text { After } \\
2 \text { weeks }\end{array}$ & $\begin{array}{l}\text { After } \\
4 \text { weeks }\end{array}$ & $\begin{array}{l}\text { After } \\
6 \text { weeks }\end{array}$ & $\begin{array}{l}\text { After } \\
3 \text { months }\end{array}$ & $\begin{array}{l}\text { After } \\
6 \text { months }\end{array}$ & $\begin{array}{l}\text { After } \\
\text { I year }\end{array}$ \\
\hline$\# I$ & $M$ & 57 & 28.03 .12 & 29.03 .12 & 03.04 .12 & 10.04 .12 & 17.04 .12 & 10.05 .12 & 31.05 .12 & 12.07 .12 & 04.10 .12 & \\
\hline$\# 2$ & $M$ & 40 & 13.04 .12 & 14.04 .12 & 19.04 .12 & 23.04 .12 & 26.04 .12 & 10.05 .12 & 31.05 .12 & 19.07.12 & 18.10 .12 & 18.04 .13 \\
\hline$\# 3$ & $\mathrm{~F}$ & 60 & 19.04 .12 & 20.04 .12 & 24.04 .12 & & & 10.05 .12 & 31.05 .12 & 19.07.12 & 18.10 .12 & 18.04 .13 \\
\hline$\# 4$ & $M$ & 54 & 02.05 .12 & 04.05 .12 & 07.05 .12 & 10.05 .12 & 14.05 .12 & 31.05 .12 & 12.06 .12 & 24.07.12 & 23.10 .12 & 16.04 .13 \\
\hline$\# 5$ & $\mathrm{~F}$ & 58 & 04.06 .12 & 06.06 .12 & 08.06 .12 & 11.06 .12 & 14.06 .12 & 05.07 .12 & 19.07 .12 & 06.09 .12 & 13.12 .12 & 06.06 .13 \\
\hline \#6 & $M$ & 75 & 20.06 .12 & 22.06 .12 & & 26.06 .12 & 02.07 .12 & 19.07.12 & 02.08 .12 & 13.09 .12 & 06.12 .12 & 20.06 .13 \\
\hline$\# 7$ & $M$ & 47 & II.07.12 & 13.07 .12 & 17.07 .12 & 19.07.12 & & 09.08 .12 & 24.08 .12 & 04.10 .12 & 10.01 .13 & \\
\hline$\# 8$ & $M$ & 74 & 15.08 .12 & 23.08 .12 & & 30.08 .12 & 03.09 .12 & & & & & \\
\hline \#9 & $M$ & 33 & 28.08 .12 & 30.08 .12 & & 05.09 .12 & & 11.10 .12 & & 22.11 .12 & 21.02 .13 & 22.08 .13 \\
\hline$\# 10$ & $\mathrm{~F}$ & 47 & 05.09 .12 & & 10.09 .12 & 14.09 .12 & & & & 08.01 .13 & 02.04 .13 & \\
\hline \#II & $M$ & 57 & 18.09 .12 & 26.09 .12 & & 05.10 .12 & 10.10 .12 & & & & & \\
\hline$\# 12$ & $M$ & 30 & 20.09 .12 & & 25.09 .12 & 28.09 .12 & & 25.10 .12 & & 20.12 .12 & 18.03 .13 & \\
\hline$\# 13$ & $\mathrm{~F}$ & 43 & 28.11 .12 & 30.11 .12 & & & & & 15.01 .13 & 05.03 .13 & 11.06 .13 & 10.12 .13 \\
\hline$\# 14$ & $M$ & 57 & & 05.12 .12 & & 07.12 .12 & & & & 28.02 .13 & 13.06 .13 & 05.12 .13 \\
\hline$\# 15$ & $M$ & 51 & 10.12 .12 & 13.12 .12 & & 17.12 .12 & & & 24.01 .13 & 07.03 .13 & 22.08 .13 & 30.01 .14 \\
\hline$\# 16$ & $\mathrm{~F}$ & 56 & 12.12 .12 & 14.12 .12 & & 17.12 .12 & & & 29.01 .13 & 12.03 .13 & 16.07 .13 & 04.02 .14 \\
\hline$\# 17$ & $\mathrm{~F}$ & 42 & 21.12 .12 & 28.12 .12 & & 02.01 .13 & & & & & & \\
\hline$\# 18$ & $M$ & 54 & 05.04 .13 & 10.04 .13 & & II.04.13 & & 02.05 .13 & 16.05 .13 & 27.06 .13 & 29.08 .13 & 03.04 .14 \\
\hline$\# 19$ & $M$ & 46 & 19.08 .13 & 22.08 .13 & & 27.08 .13 & & & & & & \\
\hline$\# 20$ & $M$ & 51 & 29.08 .13 & 03.09 .13 & & 09.09 .13 & 12.09 .13 & & 17.10 .13 & & & \\
\hline \#2I & $\mathrm{F}$ & 43 & 30.08 .13 & 04.09 .13 & & 10.09 .13 & & 26.09 .13 & & & & \\
\hline$\# 22$ & $M$ & 33 & 09.01 .14 & 11.01 .14 & & 17.01 .14 & 22.01 .14 & & & & & \\
\hline$\# 23$ & $M$ & 72 & 23.01 .14 & 28.01 .14 & & 31.01 .14 & & & & & & \\
\hline$\# 24$ & $M$ & 35 & 25.04 .14 & 06.05 .14 & & & & 27.05 .14 & & & 04.11 .14 & 15.09 .15 \\
\hline$\# 25$ & $M$ & 63 & 29.07.14 & 06.08 .14 & & I5.08.14 & & & & & & \\
\hline
\end{tabular}

Abbreviations: $\mathrm{F}$, female; $\mathrm{M}$, male.

showed declining infection parameters and a decrease within 1 or 2 days thereafter. The highest registered CRP value was $183.3 \mathrm{mg} / \mathrm{L}$ (Figure 4).

The mean leukocyte count preoperatively was $7.53 \pm 2.22 \mathrm{~nL}^{-1}$; on the first postoperative day, it was $9.30 \pm 2.27 \mathrm{~nL}^{-1}$. It declined in the following days, but stayed within the reference range.

Leukocyte count differed from the reference range of 4-10 $\mathrm{nL}^{-1}$ in some patients. One patient showed intermittent leukopenia preoperatively as well as postoperatively.

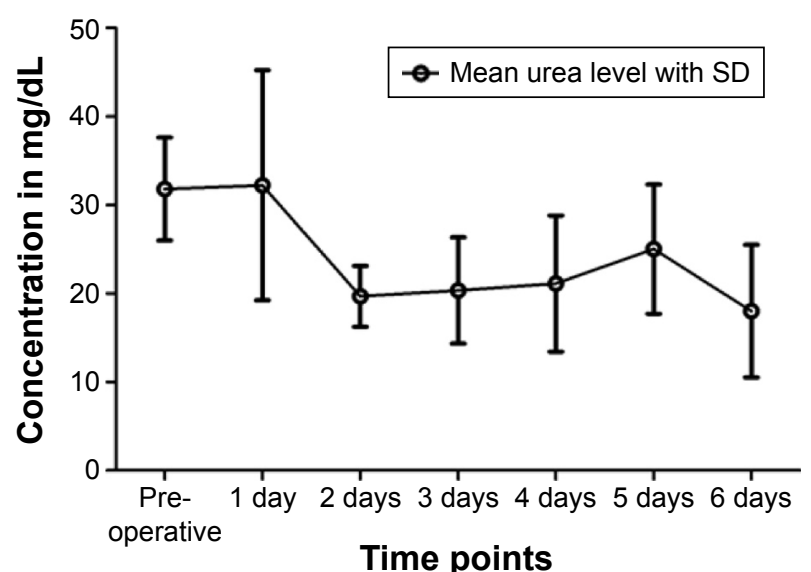

Figure 2 Mean values of urea at different time points. Abbreviation: SD, standard deviation.
Six other patients showed slight leukocytosis as high as $12.74 \mathrm{~nL}^{-1}$ (Figure 5). These values normalized within $1-2$ days.

All patients could be released within 15 days after surgery, with declining infection parameters. No allergic reactions or serious side effects were observed.

\section{Discussion}

In this prospective observational study with 25 patients treated with ETN PROtect, we confirmed that gentamicin-coated

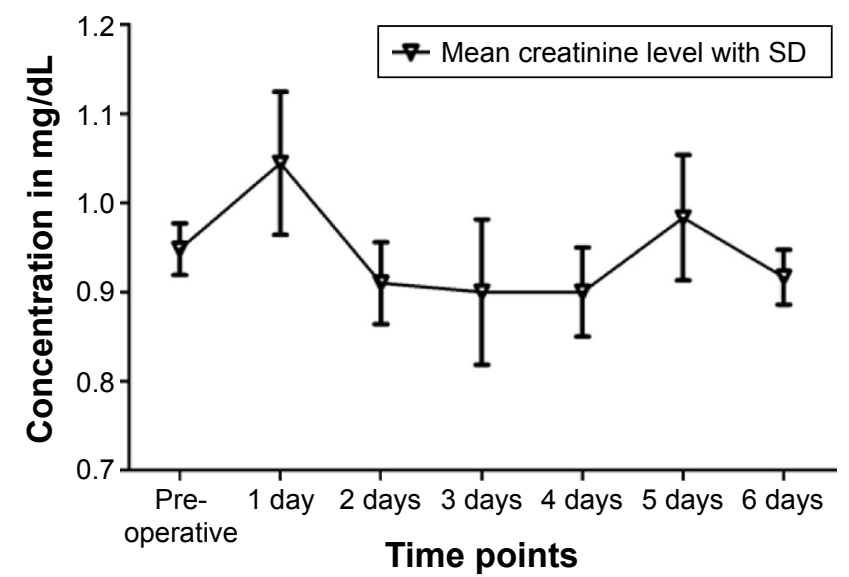

Figure 3 Mean values of creatinine at different time points. Abbreviation: SD, standard deviation. 


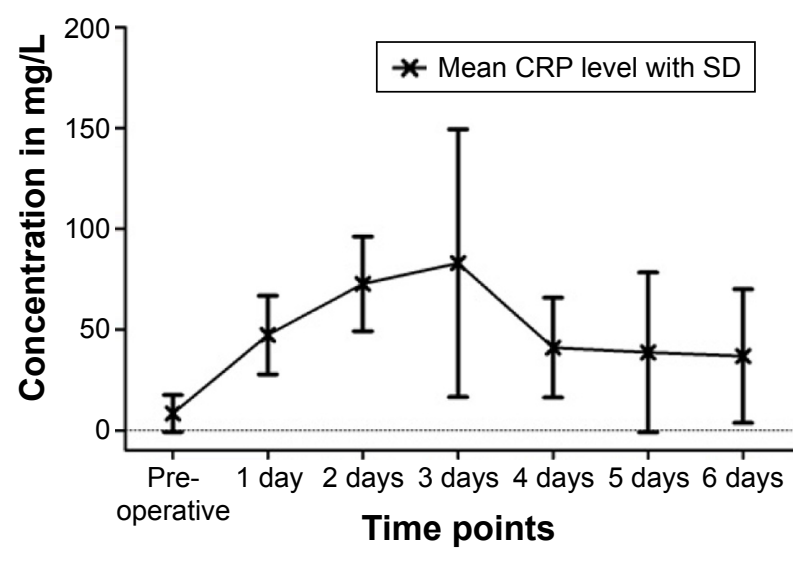

Figure 4 Mean values of CRP at different time points.

Abbreviations: CRP, C-reactive protein; SD, standard deviation.

nails do not release gentamicin above the lowest detectable level of $0.2 \mathrm{mg} / \mathrm{dL}$ into the systemic circulation.

The major strengths of this study are its prospective approach and the inclusion of serum samples from the first day after implantation. Osteitis and osteomyelitis are feared complications of orthopedic surgery. Metallic implants are especially prone to infections. ${ }^{8,11}$ Routine prophylaxis involves the perioperative administration of antibiotics, but this has the downside of systemic side effects and the danger of insufficient doses of antibiotics at the operation site. ${ }^{4,38}$ An alternative is the local application of antibiotics through drug-coated implants like ETN PROtect. The gentamicin sulfate (up to $20-50 \mathrm{mg}$ ) incorporated in the amorphous PDLLA matrix is released in an initial burst followed by a continuous phase, as in vivo and in vitro experiments have shown. ${ }^{37}$ We were able to demonstrate successful treatment with ETN PROtect in patients with increased risk for infections in the clinical setting. ${ }^{3}$ Local application of gentamicin has been proven successful and effective in the prophylaxis of infection. ${ }^{1,18,37,39}$ Local concentrations high enough for prophylaxis do not affect bone healing in a negative way. ${ }^{30} \mathrm{But}$, in order to increase

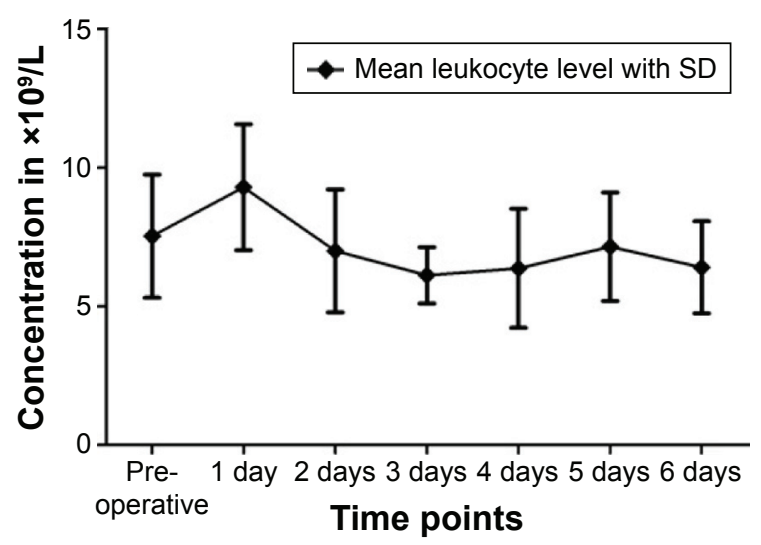

Figure 5 Mean values of leukocytes at different time points. Abbreviation: SD, standard deviation. patient safety and adequately educate patients preoperatively on the risks and effects of the treatment with ETN PROtect, we need to know if a systemic effect is possible. Consequences could be an indication for therapeutic drug monitoring and monitoring of renal function after implantation.

A serious rise of CRP above $200 \mathrm{mg} / \mathrm{L}$ within a few hours would have been suspicious for severe inflammation or bacterial infection. ${ }^{40}$ Since all increased CRP values remained below $200 \mathrm{mg} / \mathrm{L}$ and declined within a short period of time, there were no signs of postoperative infections. ${ }^{41,42}$ Leukocytosis is not only a sign of chronic inflammation, but also a sign of metabolic crisis, acute blood loss, acute hemolysis as well as pain or the body's reaction to stress. ${ }^{43}$ We have observed the change in inflammation markers due to trauma during surgery. ${ }^{42,44} \mathrm{We}$ could observe a slight average increase of urea and creatinine that remained within the standard range. Generally, urea may rise due to fever, trauma, hypovolemia, or a catabolic state of metabolism. ${ }^{42,45}$ Creatinine is primarily a sign of acute renal dysfunction, possibly severe blood loss, damages due to drugs, hemolysis, and chronic renal damage. ${ }^{42}$ Both parameters can rise to values above the upper reference range limit shortly after a surgery, due to trauma and blood loss. Altogether, the analysis of laboratory parameters showed changes matching a physiological response to surgical trauma.

One patient showed a conspicuous change in creatinine and urea. Infection parameters were also increased, but clinical course of the patient was inconspicuous. Ten days after the operation, renal retention markers were controlled and had returned to the initial value. The patient was released 14 days after surgery, with declining infection parameters. The patient's records showed a medical history of hypercholesterolemia, overweight, heartburn, back pain, and burnout, but no renal diseases. Preoperative and postoperative medication included analgesics $\left(\right.$ Voltaren $^{\circledR}$, Novalgin $\left.{ }^{\circledR}\right)$, proton-pump inhibitor (Pantozol $\left.{ }^{\circledR} 40\right)$, low-molecular-weight heparin (Clexane ${ }^{\circledR} 60$ subcutan), and single-shot antibiotic Zinacef ${ }^{\circledR}$ (cefuroxime) as prophylaxis during surgery. Due to the fact that no gentamicin was detectable in the patient's blood and renal injury is dose-dependent, we, as well as the attending physicians, do not link the deviation in laboratory parameters to the release of gentamicin. Furthermore, we could not see any clinical signs of renal failure, such as a decrease in urine production, edema, or pleural effusions. We see the intraoperative application of cefuroxime as the cause for the changes in the renal retention markers. Manufacturer's specifications and the literature indicate that cefuroxime as well as gentamicin can induce acute renal failure. ${ }^{46,47}$ Overall, no severe side effects occurred, which could be linked to systemic gentamicin exposure. 
In the course of this prospective, observational study, we were able to confirm that gentamicin-coated nails do not release gentamicin into the systemic circulation above the lowest detectable level of $0.2 \mathrm{mg} / \mathrm{dL}$. Our findings suggest that no relevant amount of gentamicin for causing a systemic effect is released into the systemic circulation, although in vivo studies showed high local concentrations of gentamicin on the implant site. ${ }^{11,18,30}$ This fits our observation that no severe side effects could be linked to implantation. Postoperative monitoring of renal function does not seem necessary after implantation of ETN PROtect. Furthermore, no allergic reactions were observed during our study.

The most important strength of this study is its prospective approach. Furthermore, we not only measured gentamicin levels, but also analyzed parameters for infection and renal failure. One advantage of our study is that we were able to take serum samples before operation and on the first day after the operation. In vivo and in vitro studies showed that the release of gentamicin from PDLLA-coating occurs in an initial burst so one can state that evidence of gentamicin in the systemic circulation is most likely seen within hours or on the first day after implantation. ${ }^{37}$ Fuchs et al already tried to detect gentamicin in serum samples but only analyzed samples from follow-ups on days 4 and 7, week 5, and months 3 and 6 after implantation. ${ }^{11}$ This could still be improved by analyzing blood samples directly after implantation. Further point for criticism can be that there are more sensitive tools for detecting the actual plasma levels of gentamicin such as high-performance liquid chromatography. However, a study by Walenkamp et al on gentamicin-coated beads could not prove systemic side effects for gentamicin levels up to $0.4 \mu \mathrm{g} / \mathrm{mL}$; therefore, we consider $0.2 \mu \mathrm{g} / \mathrm{mL}$ to be sensitive enough. ${ }^{48}$

\section{Conclusion}

Our findings suggest that no relevant amount of gentamicin is released into the circulation that could cause a systemic effect. We conclude that serious side effects due to systemic gentamicin release by gentamicin-coated tibia nails are not to be feared. Postoperative monitoring of renal function does not seem necessary because of the implantation of ETN PROtect. In our opinion, ETN PROtect is an important strategy for infection prophylaxis and safe in clinical use.

\section{Acknowledgments}

The authors have revealed all financial and personal relationships to other persons and organizations that could inappropriately influence (bias) this work.

\section{Disclosure}

GS is a consultant for SYNTHES USA and owns a patent on gentamicin coating of implants. The authors report no other conflicts of interest in this work.

\section{References}

1. Schmidmaier G, Lucke M, Wildemann B, Haas NP, Raschke M. Prophylaxis and treatment of implant-related infections by antibioticcoated implants: a review. Injury. 2006;37(Suppl 2):S105-S112.

2. Schmidmaier G, Moghaddam A. [Long bone nonunion]. Z Orthop Unfall. 2015;153(6):659-676.

3. Moghaddam A, Zietzschmann S, Bruckner T, Schmidmaier G. Treatment of atrophic tibia non-unions according to "diamond concept: Results of one- and two-step treatment. Injury. 2015;46(Suppl 4): S39-S50.

4. Lima AL, Oliveira PR, Carvalho VC, Cimerman S, Savio E; Diretrizes Panamericanas para el Tratamiento de las Osteomielitis e Infecciones de Tejidos Blandos Group; Recommendations for the treatment of osteomyelitis. Braz J Infect Dis. 2014;18(5):526-534.

5. Miska M, Findeisen S, Tanner M, et al. Treatment of nonunions in fractures of the humeral shaft according to the Diamond Concept. Bone Joint J. 2016;98-B(1):81-87.

6. Moghaddam A, Ermisch C, Schmidmaier G. Non-union current treatment concept. Shafa Ortho J. In Press 2015.

7. Halawi MJ, Morwood MP. Acute management of open fractures: An evidence-based review. Orthopedics. 2015;38(11):e1025-e1033.

8. Makridis KG, Tosounidis T, Giannoudis PV. Management of infection after intramedullary nailing of long bone fractures: treatment protocols and outcomes. Open Orthop J. 2013;7:219-226.

9. Moghaddam A, Zimmermann G, Hammer K, Bruckner T, Grützner PA, von Recum J. Cigarette smoking influences the clinical and occupational outcome of patients with tibial shaft fractures. Injury. 2011;42(12): 1435-1442.

10. Moghaddam-Alvandi A, Zimmermann G, Hammer K, Bruckner T, Grützner PA, von Recum J. Cigarette smoking influences the clinical and occupational outcome of patients with tibial shaft fractures. Injury. 2013; 44(11):1670-1671.

11. Fuchs T, Stange R, Schmidmaier G, Raschke MJ. The use of gentamicincoated nails in the tibia: preliminary results of a prospective study. Arch Orthop Trauma Surg. 2011;131(10):1419-1425.

12. Gaebler C, Berger U, Schandelmaier P. Rates and odds ratios for complications in closed and open tibial fractures treated with unreamed, small diameter tibial nails: a multicenter analysis of 467 cases. J Orthop Trauma. 2001;15(6):415-423.

13. Noumi T, Yokoyama K, Ohtsuka H, Nakamura K, Itoman M. Intramedullary nailing for open fractures of the femoral shaft: evaluation of contributing factors on deep infection and nonunion using multivariate analysis. Injury. 2005;36(9):1085-1093.

14. Dhammi IK, Ul Haq R, Kumar S. Prophylactic antibiotics in orthopedic surgery: Controversial issues in its use. Indian J Orthop. 2015;49(4): 373-376.

15. Mendel V, Simanowski HJ, Scholz HC, Heymann H. Therapy with gentamicin-PMMA beads, gentamicin-collagen sponge, and cefazolin for experimental osteomyelitis due to Staphylococcus aureus in rats. Arch Orthop Trauma Surg. 2005;125(6):363-368.

16. Loca D, Sokolova M, Locs J, Smirnova A, Irbe Z. Calcium phosphate bone cements for local vancomycin delivery. Mater Sci Eng CMater Biol Appl. 2015;49:106-113.

17. Letsch R, Rosenthal E, Joka T. [Local antibiotic administration in osteomyelitis treatment - a comparative study with two different carrier substances]. Aktuelle Traumatol. 1993;23(7):324-329.

18. Lucke M, Wildemann B, Sadoni S, et al. Systemic versus local application of gentamicin in prophylaxis of implant-related osteomyelitis in a rat model. Bone. 2005;36(5):770-778. 
19. Knaepler H. Local application of gentamicin-containing collagen implant in the prophylaxis and treatment of surgical site infection in orthopaedic surgery. Int J Surg. 2012;10(Supp1 1):S15-S20.

20. Folsch C, Federmann M, Kuehn KD, et al. Coating with a novel gentamicin palmitate formulation prevents implant-associated osteomyelitis induced by methicillin-susceptible Staphylococcus aureus in a rat model. Int Orthop. 2015;39(5):981-988.

21. Inzana JA, Schwarz EM, Kates SL, Awad HA. Biomaterials approaches to treating implant-associated osteomyelitis. Biomaterials. 2016;81: 58-71.

22. Westhauser F, Zimmermann G, Moghaddam S, et al. Reaming in treatment of non-unions in long bones: cytokine expression course as a tool for evaluation of non-union therapy. Arch Orthop Trauma Surg. 2015; 135(8):1107-1116.

23. Kumar CG, Himabindu M, Jetty A. Microbial biosynthesis and applications of gentamicin: a critical appraisal. Crit Rev Biotechnol. 2008; 28(3):173-212.

24. Hariprasad G, Kumar M, Rani K, Kaur P, Srinivasan A. Aminoglycoside induced nephrotoxicity: molecular modeling studies of calreticulingentamicin complex. J Mol Model. 2012;18(6):2645-2652.

25. Lucke M, Schmidmaier G, Sadoni S, et al. A new model of implant-related osteomyelitis in rats. J Biomed Mater Res B Appl Biomater. 2003;67(1): 593-602.

26. Taylor GJ, Bannister GC, Calder S. Perioperative wound infection in elective orthopaedic surgery. J Hosp Infect. 1990;16(3):241-247.

27. Dapunt U, Spranger O, Gantz S. Are atrophic long-bone nonunions associated with low-grade infections? Ther Clin Risk Manag. 2015;11: 1843-1852.

28. Lopez-Novoa JM, Quiros Y, Vicente L, Morales AI, Lopez-Hernandez FJ. New insights into the mechanism of aminoglycoside nephrotoxicity: an integrative point of view. Kidney Int. 2011;79(1):33-45.

29. Lerner SA, Schmitt BA, Seligsohn R, Matz GJ. Comparative study of ototoxicity and nephrotoxicity in patients randomly assigned to treatment with amikacin or gentamicin. Am J Med. 1986;80(6b): 98-104.

30. Fassbender M, Minkwitz S, Kronbach Z, et al. Local gentamicin application does not interfere with bone healing in a rat model. Bone. 2013; 55(2):298-304.

31. World Medical Association. World Medical Association Declaration of Helsinki: ethical principles for medical research involving human subjects. JAMA. 2013;310(20):2191-2194.

32. Moghaddam A, Breier L, Haubruck P, et al. Non-unions treated with bone morphogenic protein 7 : introducing the quantitative measurement of human serum cytokine levels as promising tool in evaluation of adjunct non-union therapy. J Inflamm (Lond). 2016;13:3.
33. Bender D, Haubruck P, Boxriker S, Korff S, Schmidmaier G, Moghaddam A. Validity of subjective smoking status in orthopedic patients. Ther Clin Risk Manag. 2015;11:1297-1303.

34. Dahlgren JG, Anderson ET, Hewitt WL. Gentamicin blood levels: A guide to nephrotoxicity. Antimicrob Agents Chemother. 1975;8(1):58-62.

35. van Raaij TM, Visser LE, Vulto AG, Verhaar JA. Acute renal failure after local gentamicin treatment in an infected total knee arthroplasty. $J$ Arthroplasty. 2002;17(7):948-950.

36. Nast S, Fassbender M, Bormann N, et al. In vivo quantification of gentamicin released from an implant coating. J Biomater Appl. Epub 2016 Feb 10.

37. Vester H, Wildemann B, Schmidmaier G, Stöckle U, Lucke M. Gentamycin delivered from a PDLLA coating of metallic implants: In vivo and in vitro characterisation for local prophylaxis of implantrelated osteomyelitis. Injury. 2010;41(10):1053-1059.

38. Diefenbeck M, Muckley T, Hofmann GO. Prophylaxis and treatment of implant-related infections by local application of antibiotics. Injury. 2006;37(Suppl 2):S95-S104.

39. Lucke M, Schmidmaier G, Sadoni S, et al. Gentamicin coating of metallic implants reduces implant-related osteomyelitis in rats. Bone. 2003; 32(5):521-531.

40. Clyne B, Olshaker JS. The C-reactive protein. J Emerg Med. 1999;17(6): 1019-1025.

41. Pepys MB, Hirschfield GM. C-reactive protein: a critical update. J Clin Invest. 2003;111(12):1805-1812.

42. Gressner AM, Arndt T. Lexikon der Medizinischen Laboratoriumsdiagnostik: Band 1 Klinische Chemie. [Dictionary for Medical Laboratory Diagnostic: Volume I Clinical Chemistry]. SpringerLink: Bücher. 2007, Berlin, Heidelberg: Springer.

43. Munker R, Hiller E, Glass J, Paquette R. Modern Hematology: Biology and Clinical Management (Contemporary Hematology). 2nd ed. Totowa, NJ: Humana Press; 2007.

44. Czaplicki AP, Borger JE, Politi JR, Chambers BT, Taylor BC. Evaluation of postoperative fever and leukocytosis in patients after total hip and knee arthroplasty. J Arthroplasty. 2011;26(8):1387-1389.

45. Gowda S, Desai PB, Kulkarni SS, Hull VV, Math AA, Vernekar SN. Markers of renal function tests. N Am J Med Sci. 2010;2(4):170-173.

46. Leong CL, Thiruventhiran T. Cefuroxime-induced acute renal failure. Nephron. 2000;84(2):185.

47. Trollfors B, Suurkula M, Price JD, Norrby R. Renal function during cefuroxime treatment in patients with pre-existing renal impairment. J Antimicrob Chemother. 1980;6(5):665-670.

48. Walenkamp GH, Vree TB, van Rens TJ. Gentamicin-PMMA beads Pharmacokinetic and nephrotoxicological study. Clin Orthop Relat Res. 1986;(205):171-183.
Therapeutics and Clinical Risk Management

\section{Publish your work in this journal}

Therapeutics and Clinical Risk Management is an international, peerreviewed journal of clinical therapeutics and risk management, focusing on concise rapid reporting of clinical studies in all therapeutic areas, outcomes, safety, and programs for the effective, safe, and sustained use of medicines. This journal is indexed on PubMed Central, CAS,

\section{Dovepress}

EMBase, Scopus and the Elsevier Bibliographic databases. The manuscript management system is completely online and includes a very quick and fair peer-review system, which is all easy to use. Visit http://www.dovepress.com/testimonials.php to read real quotes from published authors. 